WHOI-79-13

LIMITS OF NEMATOSCELIS MEGALOPS IN THE NORTHWESTERN ATLANTIC

IN RELATION TO GULF STREAM COLD CORE RINGS.

11. PHYSIOLOGICAL AND DCHEMICAL EFFECTS OF EXPATRIATION

by

\author{
Steven H. Boyd, Peter H. Wiebe \\ and James L. Cox \\ WOODS HOLE OCEANOGRAPHIC INSTITUTION \\ Woods Hole, Massachusetts 02543
}

January 1979

TECHNICAL REPORT

Prepared for the Office of Naval Research under Contracts N00014-66-C-0241; NR 083-004 and N00014-74-C-0262; NR 083-004 and for the National Science Foundation under Grant DES 74-02783 A01.

Reproduction in whole or in part is permitted for any purpose of the United States Goverment. In citing this report in a bibliogrophy, the reference given should be to "Journal of Marine Research, Volume 36, 1, 1978, pp. 143-159". Approved for public release; distribution unlimited.

Approved for Distribution: George D. Grice, Chairman Department of Biology 


\title{
Limits of Nematoscelis megalops in the Northwestern Atlantic in relation to Gulf Stream cold core rings. II. Physiological and biochemical effects of expatriation
}

\author{
by Steven H. Boyd ${ }^{1}$, Peter H. Wiebe ${ }^{1}$ and James L. Cox ${ }^{2}$
}

\begin{abstract}
Nematoscelis megalops, a cold water euphausiid commonly found in Northwestern Atlantic Slope Water, is frequently transported in the cores of Gulf Stream cyclonic rings into the Sargasso Sea. The inner core made of cold Slope Water gradually assumes physical and biological characteristics of the surrounding Sargasso Sea. These changes gradually lead to a localized extinction of this species in the core of the ring. Samples of $N$. megalops taken from the same ring at 6 and 9 months after its formation show a weakened physiological and biochemical condition.

Deterioration of ring individuals is evidenced by an increase in body water content and a reduction in total body lipid, carbon, respiration rates, and nitrogen relative to Slope Water individuals. By 6 months it appears that ring $N$. megalops must supplement food intake by metabolizing some of their body protein and by 9 months they appear to use lipids as well.

A shipboard starvation experiment involving 40 Slope Water individuals showed that physiological and biochemical states similar to those found in individuals from the 9 months old ring could be duplicated in 4 days of complete starvation.
\end{abstract}

\section{Introduction}

A fundamental question in the study of oceanic plankton has been: what range of environmental conditions permits both the long-term survival and the reproduction of a species? These conditions define the normal living space of the species, both vertically and horizontally. Spatial limits are typically determined by the presence or absence of individuals at different locations and hence the limits do not, by themselves, provide a measure of suitability. Factors such as food, temperature, salinity, or predation pressure may become stressful at the extremes of the spatial distribution of the species. Such conditions may lead to reproductive failure or death only after a protracted period of degradation of the physiological conditions of the organisms, as reflected by changes in biochemical composition and energy metabolism. These biochemical changes may prove to be more realistic in defining the

1. Woods Hole Oceanographic Institution, Woods Hole, Massachusetts, 02543, U.S.A.

2. Marine Science Institute, University of California, Santa Barbara, California, 93106, U.S.A. 
limits of viable populations, especially in the case of plankton which are relatively incapable of maintaining their horizontal distribution behaviorally.

Unfavorable changes in the environment are, in the case of oceanic planktonic crustacea, determinative of their biochemical composition and metabolic rate. Energy substrates, protein or lipid, are consumed without replacement during periods of environmental stress (Orr, 1934a,b; Littlepage, 1964; Conover, 1964; Ikeda, 1974; Mayzaud, 1976; Bamstedt, 1975). Variations in biochemical composition and energy metabolism related to sex, and size of organism, latitudinal range, and seasonal effects have also been documented. However, little is known about their interaction with environmental stress.

Gulf Stream cold core rings offer a unique setting for the study of physically induced environmental stress in an oceanic environment. Gulf Stream cold core rings are formed from large meanders of the Gulf Stream which then move out into the Sargasso Sea (Parker, 1971). The central region of the ring contains Slope Water and its associated plankton community (Wiebe et al., 1976; Wiebe and Boyd, 1978; Ortner et al., in prep). As a ring ages, it gradually assumes the characteristics of the surrounding Sargasso Sea, through increased heating from the surface and mixing with adjacent waters. Thus the water column warms and increases in salinity, the oxygen minimum layer deepens, and the nutrient concentration of the euphotic zone decreases. After only a few months (approximately 3 to 6) the phytoplankton population in the ring approaches that of the Sargasso Sea with respect to both abundance and composition (Wiebe et al., 1976; Ortner et al., in prep.). The transition from a predominantly Slope Water fauna to that characteristic of the Sargasso Sea takes place more slowly (at least 12 months, Wiebe et al., 1976). Rings may last as long as two years (Parker, 1971).

Nematoscelis megalops, a large, Slope Water euphausiid, found south of the Gulf Stream only in association with cold core rings, appears to be a representative cold water euphausiid species with respect to its distribution, chemical composition, growth rate, and respiration (Raymont and Conover, 1961; Mauchline and Fisher, 1969; Gopalakrishnan, 1974; Wiebe and Boyd, 1978). The alteration of $N$. megalops's environment associated with ring decay ultimately leads to its local extinction. In this paper we present evidence to support the hypothesis that environmental alterations gradually degrade the physiological state of expatriated populations of the species. We compare biochemical and physiological properties of populations within the ring with those of populations in its home range-the Slope Water.

\section{Methods and materials}

a. Collection techniques. Samples of Nematoscelis megalops were taken from both the Slope Water and a Gulf Stream cold core ring (designated Ring D by NAVOCEANO) on two successive cruises-Chain 125 (August 1975) and 


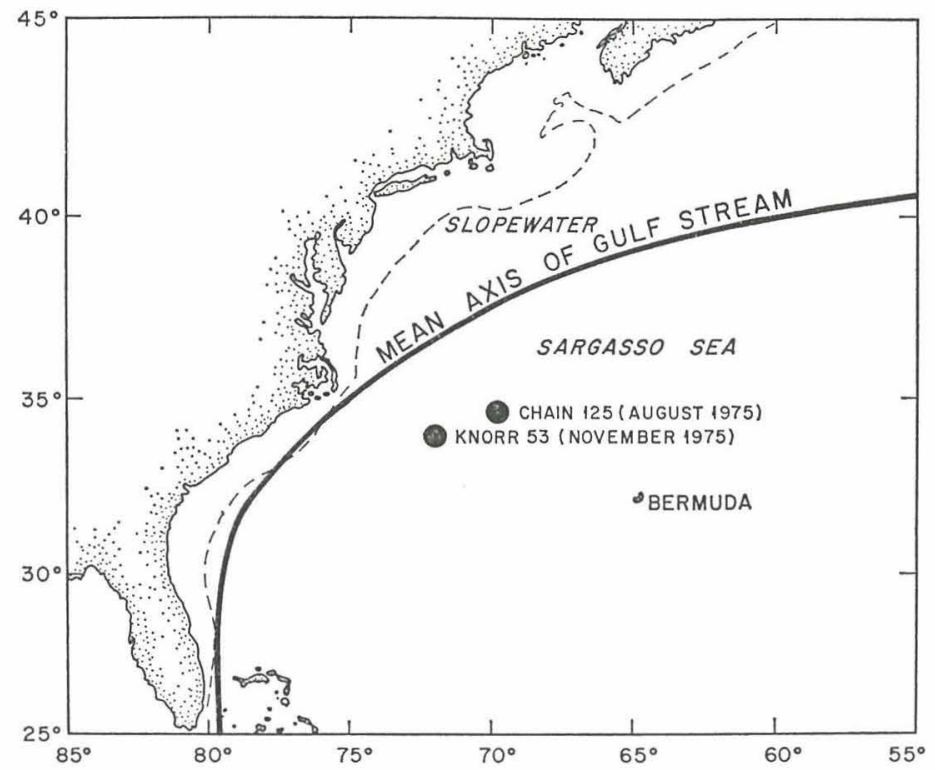

Figure 1. Position of Ring D at 6 months (Chain 125) and 9 months (Knorr 53) in the North West Atlantic.

Knorr 53 (November 1975) (Fig. 1). This ring had formed approximately six months before the first cruise. At each station $N$. megalops was removed from collections which were taken at night with a 10' Isaacs Kidd Midwater Trawl (IKMT) towed from approximately $750 \mathrm{~m}$ to the surface. Individuals were also obtained from night MOCNESS $\left(1 \mathrm{~m}^{2}\right)$ plankton tows which sampled at $100 \mathrm{~m}$ intervals, most often from $800 \mathrm{~m}$ to the surface. (See Wiebe and Boyd (1978) for more details about the plankton tows.)

Individuals for live work were collected with a closing $1 \mathrm{~m}$ net equipped with $.505 \mu$ mesh and an enlarged cod end bucket. The net was slowly fished for 15-25 minutes at depths of maximum $N$. megalops abundance as determined by a preceding MOCNESS tow. The ship was then stopped and the net closed. Those in the "best" condition were obtained if the net was quickly retrieved to the seasonal thermocline, and then gradually brought through the region of rapid temperature change. This procedure was the most successful presumably because it reduced thermal shock.

Our measurements included analyses of freshly collected individuals for sex, wet and dry weight, total lipid, carbon and nitrogen, as well as supplemental information derived from respiration and shipboard starvation experiments. Individuals for biochemical analyses were carefully picked from each collection and frozen at $-15^{\circ} \mathrm{C}$ in plastic Petri dishes. Only those in good condition were chosen. The entire sorting process usually took less than 15 minutes. The remainer of the 
plankton sample, if taken by the MOCNESS, was preserved in $5 \%$ buffered formalin and later used for estimates of numerical abundance.

b. Biomass/abundance estimates. Frozen N. megalops were thawed, examined microscopically for physical condition, carapace length, and sex. Individuals judged to be physically intact were weighed, dried to constant weight at $60^{\circ} \mathrm{C}$ and reweighed $( \pm 0.01 \mathrm{mg})$. Carapace lengths were also determined from preserved specimens, as measured along the midline from the eye socket inner carapace edge to the most posterior leading edge (Rudd, 1936).

Estimates of numerical abundance were based on night tows taken in the ring and Slope Water on Chain 125 (ring age $=6$ months) and Knorr 53 (ring age $=9$ months). (See Wiebe and Boyd, 1978, for specific details.)

c. Biochemical composition. The total lipid of $N$. megalops was measured using the Bligh and Dyer (1959) modification of the gravimetric procedure of Folch, Lees and Sloane Stanley (1957). Single frozen individuals were placed in a $10 \mathrm{ml}$ glass homogenizer and ground for 1 min with three successive rinses of a $6 \mathrm{ml}$ chloroform methanol solution ( $2: 1$ by volume). Each rinse was filtered through a Whatman \#4 qualitative filter into a separatory funnel. The residue remaining on the filter was rinsed with $.05 \mathrm{~N} \mathrm{KCL}$ aqueous solution. The final proportions of chloroform, methanol and water were $1: 2: .8$. The resulting biphasic solution in the separatory funnel was allowed to sit at least 24 hours by which time the lower fraction containing the lipid had fully separated. The lower fraction was then transferred to a preweighed aluminum pan and dried in a nitrogen atmosphere. Total lipids were defined as the difference between the pan's initial and final weight.

Total carbon and nitrogen of single individuals were determined with a modified Model $185 \mathrm{~F}+\mathrm{M}$ CHN analyzer. Those greater than $7.5 \mathrm{mg}$ dry wt were ground and carbon and nitrogen were determined on aliquots which were then averaged.

Percent water content of individual animals was calculated from the difference between the wet and dry weight.

d. Oxygen consumption measurements. Oxygen uptake measurements were made on board ship and later in the laboratory with animals taken on Knorr 53. We used a modified all-glass differential micro-respirometer (Greunbaum, Siegel, Schultz, and Kirk, 1955) in which the capillary bores were modified to $0.35 \mathrm{~mm}$ diameter and the respirometry vessels were enlarged to a $10 \mathrm{ml}$ capacity. This instrument combines simplicity with small size, and makes possible semi-continuous series of measurements over a short period of time. All measurements were run at $10^{\circ} \pm$ $1.5^{\circ} \mathrm{C}$.

e. Starvation study. A shipboard study was conducted using Slope Water $N$. megalops to test the physiological and biochemical effects of starvation. Once on board the euphausiids were kept in reduced light. Those used solely for respiration 
were kept in 20 liter carboys at $10^{\circ} \mathrm{C}$ (10-15 individuals/carboy) for at least $6 \mathrm{hrs}$ before a respirometry run.

A large number of individuals were collected at night with a $1 \mathrm{~m}$ net tow. Nineteen of these were frozen immediately for biochemical analysis and three were used to measure oxygen uptake. These constitute the initial respiration values. An additional 40 individuals were placed in 2 liter glass containers with surface seawater, 5 to a container. Each of the eight containers was assigned a number and on consecutive days random pairs of containers were arbitrarily selected for analysis. However, by the fourth day, all individuals except one in the last four containers had died. On each day the live individuals from one container were frozen for biochemical analysis. Those in the second container were used for respiration measurements and subsequently frozen for biochemical analyses, regardless of whether they survived the respiration run. The maintenance temperature $\left(10^{\circ} \mathrm{C} \pm 1.5\right)$ approximates the mean habitat temperature of $N$. megalops as measured by the MOCNESS. The sea water used in maintaining individuals was collected from the surface in the same area in which the individuals were collected. Sea water used in the microrespirometry was Whatman GFC glass fiber filtered, at 4.5 psi.

\section{Results}

\section{a. Biochemical Composition}

Water Content. Percent water content ([dry weight/wet weight] $\times 100)$ of ring individuals $(\bar{X}=86.2, n=29)$ was significantly higher than Slope Water individuals $(\bar{X}=82.8, n=44)$ Chain 125 collections $(\mathrm{P}<0.001$, Mann Whitney $\mathrm{U}$ test). Knorr 53 showed a similar significant difference between ring $(\bar{X}=85.4, n$ $=63)$ and Slope Water $(\bar{X}=80.7, n=83)$ specimens. Because of the higher water content of ring individuals, relationships expressed on a dry weight basis show somewhat different trends than those expressed on a wet weight basis. Wet weight based values are probably more valid for comparisons since these more closely reflect the natural state of the organisms as emphasized by Childress (1977) thus all measurements having a weight-specific component imply wet weights.

Lipid content. Variations in total lipid weight of individual $N$. megalops are shown in Figure 2. Total lipid weights ranged between $0.4 \mathrm{mg}$ to $3.7 \mathrm{mg}$ per individual. Lipid content expressed as $\%$ wet weight ranged between $0.3 \%$ and $5.8 \%$. Lipid weight was positively correlated with wet weight for both of the Slope Water data sets and the 6 months (Chain 125) ring data set. There was no correlation between these two variables in the ring at 9 months. The lipid weights on a percentage basis were independent of body size, although the single individual observed in the large size class in the ring had the lowest percent lipid of wet weight observed. 


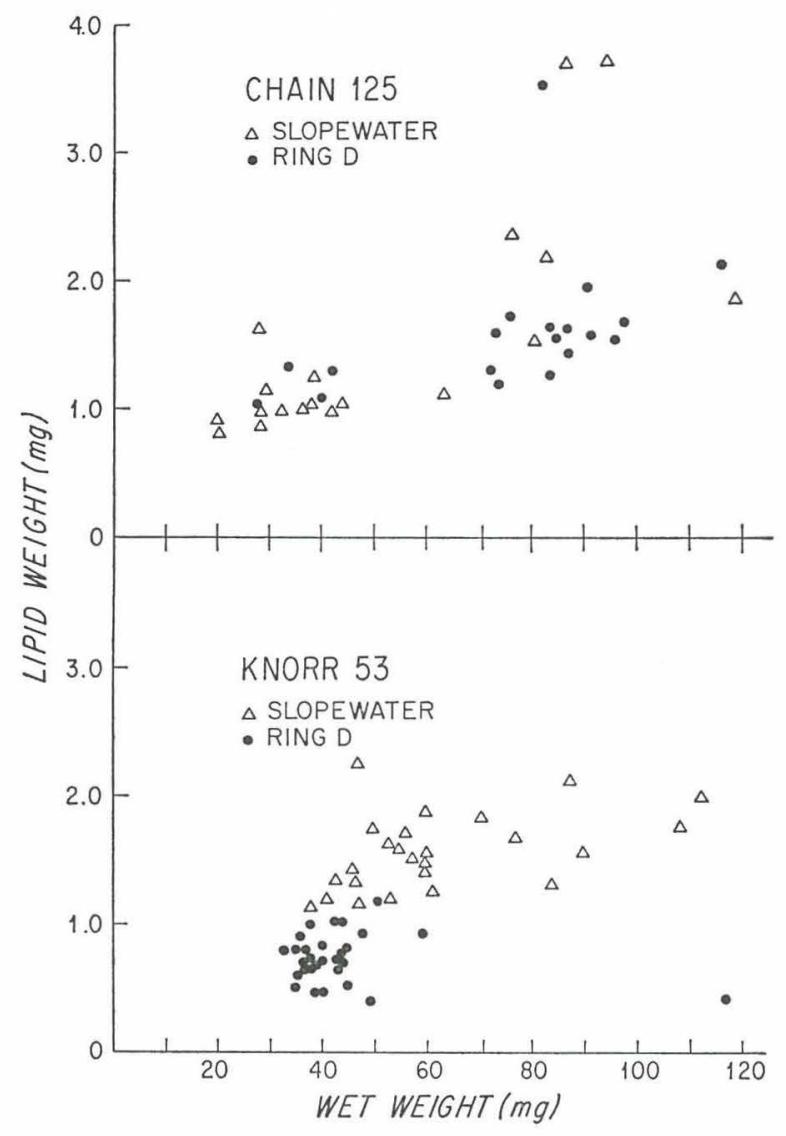

Figure 2. A comparison of Nematoscelis megalops total lipid weights to individual wet weights for cruises Chain 125 and Knorr 53.

Lipid contents for Chain 125 Slope Water and ring individuals were not significantly different $(P>.05$ Mann-Whitney U. Test). This implies that at least up to six months those animals in the ring were similar to those in the Slope Water with respect to total lipids. At 9 months in ring D total $N$. megalops lipid levels were significantly different from the Slope Water $(P<.01$ Mann-Whitney). While lipid contents of individuals in the Slope Water continued to increase, those in the ring decreased, not only in total lipid weight but also in \% lipid of wet weight.

Carbon. Total carbon, expressed as percentage of wet weight (Fig. 3) is a relative measure of organic matter primarily in the form of lipid, carbohydrate, chitin and to a lesser degree protein. It is interesting that $N$. megalops caught in the ring at 6 months (Chain 125) had a significantly lower carbon content than those in the Slope Water $(P<.05$ Mann-Whitney). This implies enhanced nonlipid carbon consumption by ring animals. 


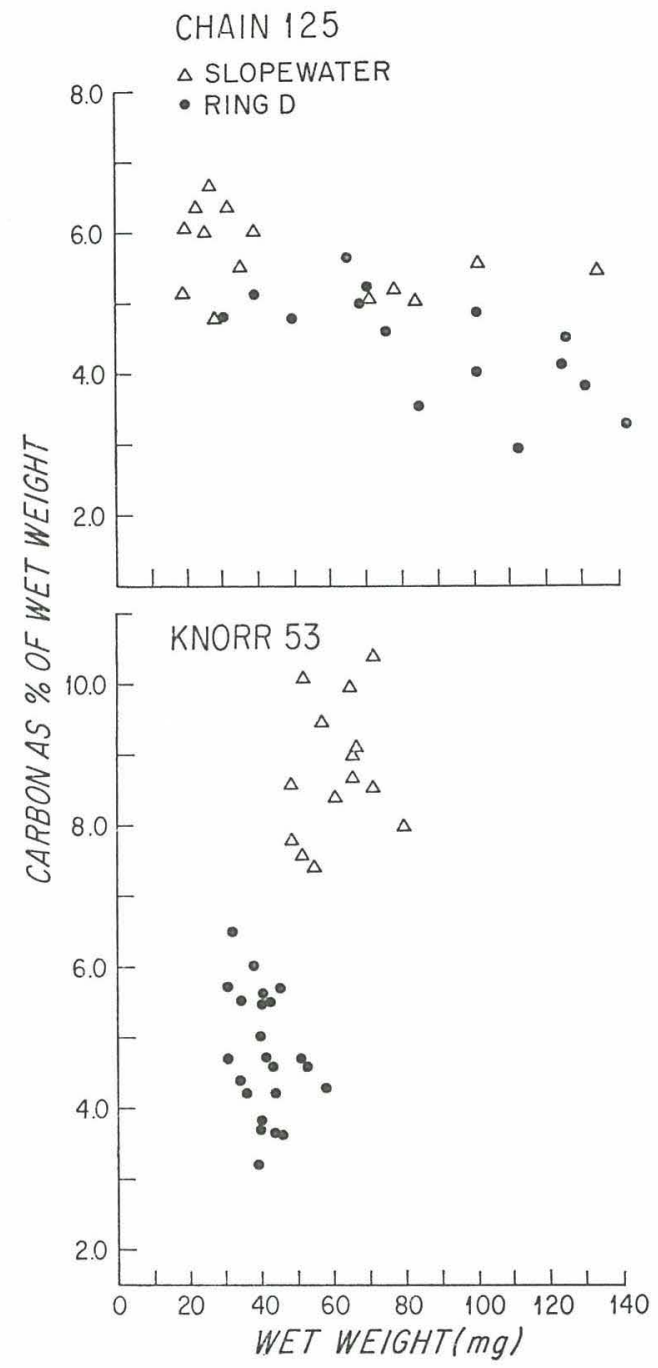

Figure 3. A comparison of Nematoscelis megalops total carbon as a percent of wet weight to individual wet weight for cruises Chain 125 and Knorr 53.

The average carbon content of 9 month ring individuals is approximately half that of the $N$. megalops in the Slope Water. In the 3 month interval between cruises, the percent carbon of ring individuals remained unchanged while the Slope Water population nearly doubled in carbon content.

Nitrogen. Total nitrogen expressed in percent of wet weight shows a trend similar to that of carbon (Fig. 4). Analysis of the Chain 125 ring and Slope Water nitrogen indicates that ring individuals had a significantly lower percent nitrogen content 


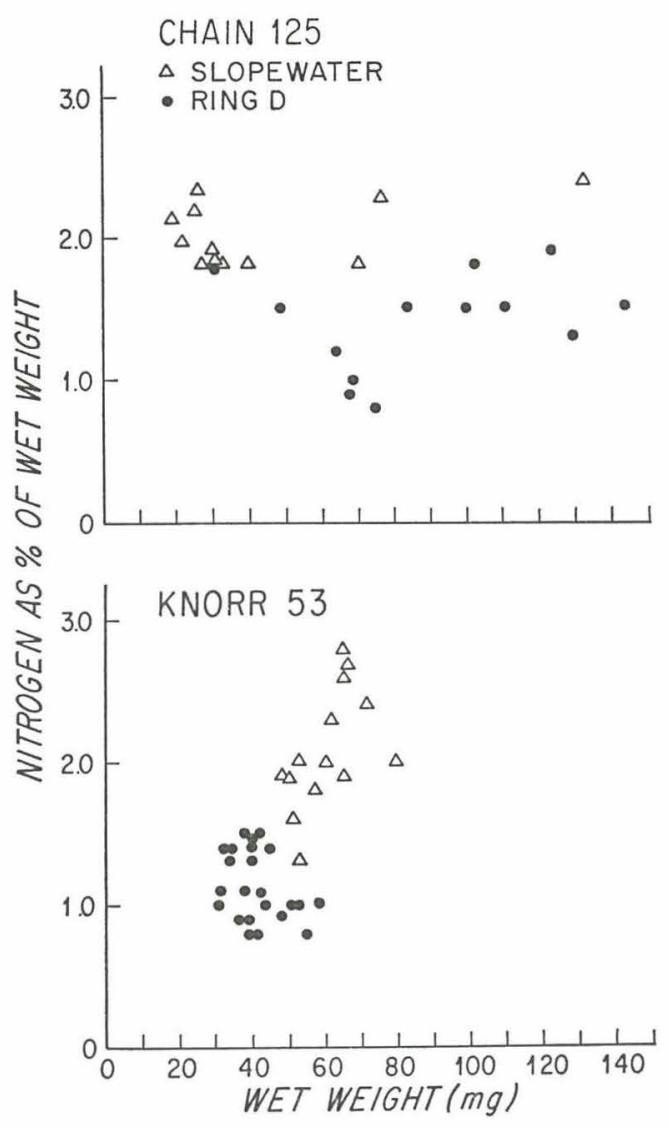

Figure 4. A comparison of Nematoscelis megalops nitrogen as a percent of wet weight to wet weight for cruises Chain 125 and Knorr 53.

than those in the Slope Water $(P<.005$ Mann-Whitney). This relationship also suggests that a substantial change in the metabolic processes of ring individuals had occurred prior to 6 months and may be related to a change in protein, nucleic acid or chitin metabolism. Total nitrogen levels significantly declined between 6 and 9 months in ring individuals while those from Slope Water remained unchanged.

Carbon/Nitrogen. Carbon and nitrogen plotted as a percent of wet showed Slope Water and ring populations separating as distinct clusters for each cruise (Fig. 5). The utility of this relationship is that it allows a graphic comparison of components that best separate the two populations. For example, in the cluster for the 6 month ring it appears that percent nitrogen is a more important determinant of cluster separation, while both carbon and nitrogen in the 9 month ring cluster seem to cause a deviation from the Slope Water cluster to a similar degree. 


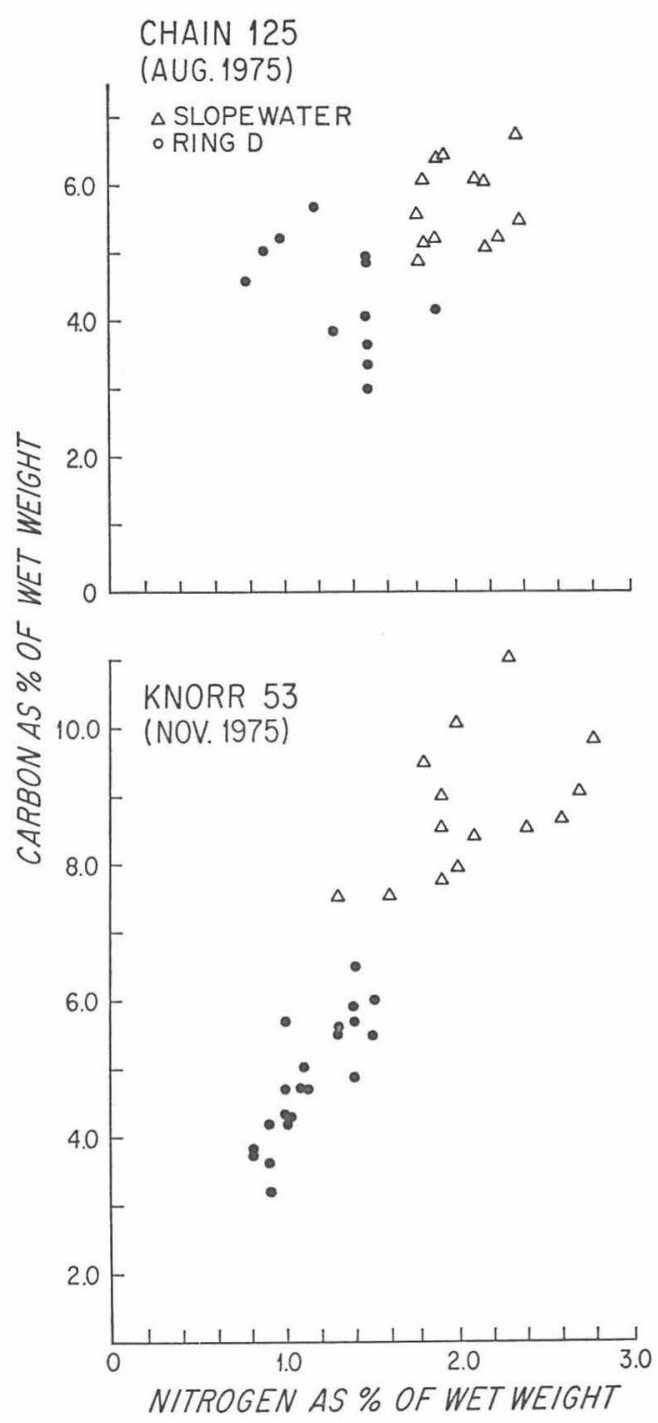

Figure 5. A comparison of Nematoscelis megalops percents carbon and nitrogen of wet weight for cruises Chain 125 and Knorr 53.

\section{b. Metabolism and growth}

Respiration rates. Rates of oxygen consumption of animals from the Knorr 53 ( 9 month) collections were measured after a 6 hour acclimation period and are considered to be between standard and active rates (Childress, 1977). Oxygen consumption of ring animals averaged $70 \mu \mathrm{l} \mathrm{O}_{2} / \mathrm{g}$ wet weight/hr. (range 45.7104.1, $n=4$ ). These measurements were obtained from attempts on 31 animals, 
Table 1. Comparison of mean wet weight of Nematoscelis megalops individuals in the GI and GII size classes in the Slope Waters and ring D for Chain 125 and Knorr 53. One standard deviation shown in parenthesis.

Chain 125, August 1975

Knorr 53, November 1975

Slope Water
GI $\quad$ GII

$86.73 \quad 30.40$

(26.16)

(8.00)

85.38

(13.33)

50.09

(9.68)

\begin{tabular}{|c|c|}
\hline \multicolumn{2}{|c|}{ Ring } \\
\hline GI & GII \\
\hline 78.14 & 33.83 \\
\hline (17.10) & $(5.75)$ \\
\hline
\end{tabular}

- $\quad 42.00$

27 of which died during the 30 minute respiration experiment. In contrast, 37 Slope Water animals were measured with no mortality. Oxygen consumption averaged $680 \mu 10_{2} / g$ wet weight/hr. (range 492-873) almost a factor of 10 higher than ring observations. However, ring animals were less active than Slope Water animals and part of the differences in respiratory rates may be attributable to differences in equilibration rates caused by these activity differences.

Carapace lengths. Fig. 7 of Wiebe and Boyd (1978) illustrates both sets of Slope Water collections have a bimodal size distribution. Similarly, in Ring D at 6 months, carapace measurements show two contracted size frequency peaks (GI and GII) that appear to closely correspond to the similar GI and GII age classes in the Slope Water samples. In Ring D at 9 months only a single size class (GII) was present. Growth measured in terms of mean carapace length increase was most rapid in the Slope Water GI size class averaging $0.9 \mathrm{~mm}$ in 90 days. Animals of the GII size class in Ring D over the same interval averaged $0.1 \mathrm{~mm}$.

Wet weight. Only mean wet and dry weight of the GI size classes can be compared owing to the reduction to a single weight frequency class in the 9 month ring (Table 1). In 90 days between collections Slope Water, N. megalops increased $.22 \mathrm{mg}$ wet wt/day while ring animals grew but $.09 \mathrm{mg}$ wet wt/day. After 9 months in ring $\mathrm{D}$ the average $N$. megalops was $84 \%$ wet wt and $67 \%$ dry wt of the corresponding size class in the Slope Water, although they were about equal when the ring was 6 months old. In the three month interval between cruises percent weight gain averaged $39 \%$ in the Slope Water and $19 \%$ in Ring D. This reduction in weight gain for ring D individuals parallels the lowered carapace length increases noted above.

\section{c. Population structure and abundance}

Sex ratio. In adult euphausiids, sex is typically determined by examination of the morphological characteristics associated with the first set of pleopods. Males have a modified endopodite known as a petasma. Females lack this modification 


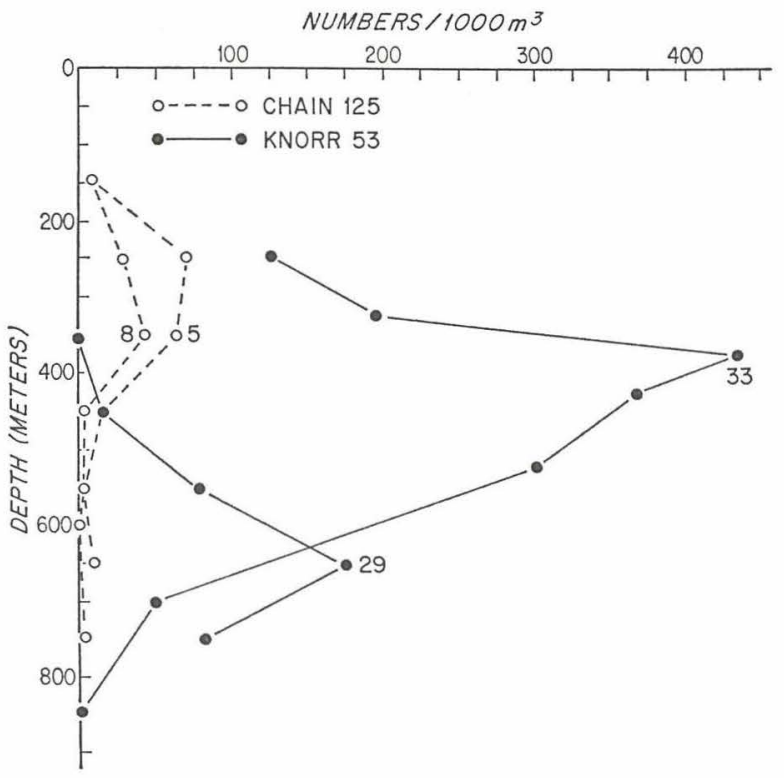

Figure 6. Vertical distributions of Nematoscelis megalops taken from night tows in Ring D at 6 months (MOCNESS tows 8, 5) and Ring D at 9 months (33, 29). Abundance is numbers per $1000 \mathrm{~m}^{3}$ for each interval sampled.

and have a simple leaf-like plate. In this study males were determined solely by the presence of the petasma.

In the Slope Water ratios of females to males averaged 51:1 for Chain 125 and 1.5:1 for Knorr 53. The situation in the ring contrasted significantly. In ring D at 6 months the sex ratio was $114: 1$, whereas at 9 months no mature males were found in more than 1400 individuals inspected. The lack of or change in morphological characteristics of adult males was further investigated by microscopic examination of the endopodites of first pleopods. Males and females of Slope Water $N$. megalops were readily separable. In addition, we observed individuals collected in the ring that had rudimentary petasma development, although they were similar in size to mature males in the Slope Water.

\section{Vertical distribution and numerical abundance}

In our Slope Water collections $N$. megalops typically occurred in the upper $600 \mathrm{~m}$ with most individuals in the population occurring above 350 meters (see Wiebe and Boyd, 1978). The vertical distribution patterns observed in the 6 month ring (Chain 125) was similar except a larger fraction was present below $350 \mathrm{~m}$ and individuals occurred down to $800 \mathrm{~m}$. On the second cruise to ring D (Knorr 53, 9 months) the vertical distribution exhibited a definite shift downward with the major proportion of the population occurring below $350 \mathrm{~m}$. Numerical abundance 
Table 2. Comparison of mean biochemical and physiological measurements for Nematoscelis megalops populations in the Slope Water and Ring D from Chain 125 and Knorr 53. (Distribution of data is shown in Figures 2-6.)

\begin{tabular}{|c|c|c|c|c|c|c|c|c|}
\hline & \multicolumn{4}{|c|}{ Chain 125} & \multicolumn{4}{|c|}{ Knorr 53} \\
\hline & & ing & Slope & Water & Rin & & Slope & Water \\
\hline $\begin{array}{l}\text { Weight (mg) } \\
\text { Wet (Dry) }\end{array}$ & 33.83 & (4.97) & 30.40 & $(5.47)$ & 42.00 & $(6.17)$ & 50.09 & (9.27) \\
\hline $\begin{array}{l}\% \text { Lipid } \\
\text { wet weight }\end{array}$ & 2.6 & & 2.8 & & 1.8 & & 3.3 & \\
\hline $\begin{array}{l}\% \text { Carbon } \\
\text { Wet (Dry) }\end{array}$ & 4.4 & $(32.1)$ & 5.7 & $(32.5)$ & 4.8 & $(32.1)$ & 9.0 & $(45.6)$ \\
\hline $\begin{array}{l}\% \text { Nitrogen } \\
\text { Wet (Dry) }\end{array}$ & 1.4 & (10.4) & 2.1 & (10.7) & 1.0 & (7.3) & 1.9 & (10.6) \\
\hline$\% \mathrm{H}_{2} \mathrm{O}$ & 86.2 & & 82.8 & & 85.4 & & 80.7 & \\
\hline $\begin{array}{l}\text { Respiration } \\
\text { (ul/gm/hr) }\end{array}$ & - & & - & & 70.0 & & 682.0 & \\
\hline No. Age classes & 2 & & 2 & & 1 & & 2 & \\
\hline $\begin{array}{l}\text { Sex } \\
\text { Female:Male }\end{array}$ & $113.5: 1$ & & $51: 1$ & & 1461:0 & & $1.5: 1$ & \\
\hline $\begin{array}{l}X \text { Depth of } \\
\text { occurrence m }\end{array}$ & 320 & & 240 & & 545 & & 280 & \\
\hline $\begin{array}{l}\bar{X} \text { Carapace } \\
\text { length mm }\end{array}$ & 3.63 & & 3.19 & & 3.75 & & 4.12 & \\
\hline $\begin{array}{c}X \text { Abundance } \\
\mathrm{m}^{2} \text { (range) }\end{array}$ & $\begin{array}{c}13.3 \\
(17.3-9.3)\end{array}$ & & - & & $\begin{array}{c}91.4 \\
(148.2-34.3)\end{array}$ & & - & \\
\hline
\end{tabular}

of $N$. megalops taken from night MOCNESS tows in ring D at 6 and 9 months are shown in Figure 6. MOCNESS tows 5 and 8 were taken on Chain 125 one day apart near the ring core. Tows 29 and 33 of Knorr 53 were separated by 2 days. Nematoscelis megalops in ring $\mathrm{D}$ at 6 months average 13.3 individuals per $\mathrm{m}^{2}$ under a column approximately $800 \mathrm{~m}$ deep, while in the 9 month ring the two tows average 91.4

Table 2 contains a summary of the biochemical and physiological results.

d. Starvation study. Since maintenance of oceanic euphausiids under laboratory conditions is extremely difficult because of the potential for high mortality from unknown causes and because we were not able to maintain and feed individuals as controls, these data must be interpreted with caution. While no individuals sur- 


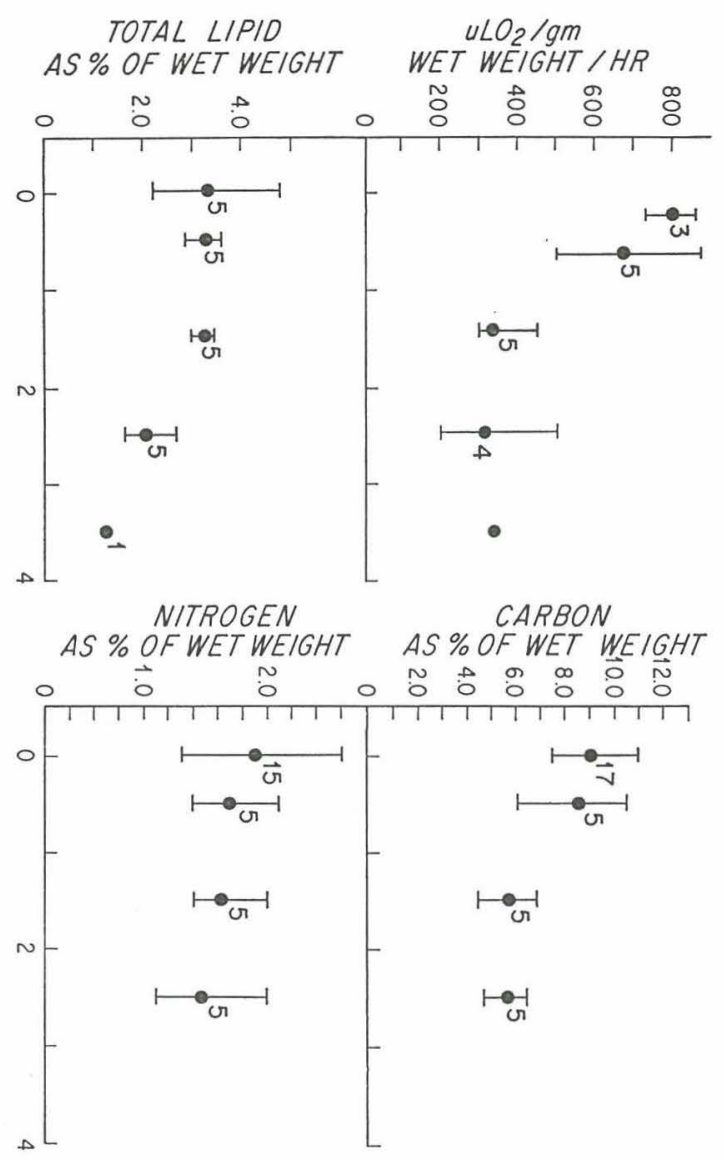

Figure 7. Shipboard starvation study comparing changes in respiration, total lipids, carbon and nitrogen percentages of wet weight through time in days. Blacked circles depict the mean and the vertical bars depict the range of each data set. Beside each circle is the number of individuals examined.

vived the shipboard study longer than 4 days, a reduction in percents carbon and nitrogen began within 2 days, with respiration rates changing more quickly (Fig. 7). Percent water was the most variable although it increased in the 4 day interval. The cursory nature of the study limits interpretation although it appears that acute stress associated with starvation and containment results in reduced carbon and nitrogen levels approximating those found in a ring 6 months of age or older. The rapidity in which complete starvation affected $N$. megalops in this experiment appears to point up the gradual nature of food deprivation in the cold core ring system and suggests that food items for $N$. megalops must be reduced or shifted in type rather slowly. 


\section{Discussion}

Nutritional studies based on confinement of crustacean zooplankton in laboratory systems have typically shown that a lack of food results in metabolic consumption of body lipid and/or protein, often in alternating sequence. These changes are reflected in total carbon and nitrogen and in carbon to nitrogen ratios. During starvation, the percentage of water in tissues gradually increases. Respiratory rates decline and moulting and growth slow or completely stop (see review of Ikeda, 1974). Field studies have suggested that seasonal or geographic reductions in the amount and quality of food can cause changes in the physiological condition of natural oceanic populations (Omori, 1970; Ikeda, 1971; Bamstedt, 1976). Omori (1970) found that Calanus cristatus transported out of its home range responded to a consequent reduction in food supply by altered biochemical composition, lowered respiration rate, and sex-ratio changes.

Since the bulk of the population of Nematoscelis megalops lives below the euphotic zone (Wiebe and Boyd, 1978) it can reasonably be assumed that as an adult it is not a herbivore. Mauchline and Fisher (1969) state that its mouth parts are not those of a herbivore. Its position in the water column suggests that it obtains its food from euphotic zone detritus and fecal pellets and from zooplankton migrating to and from the euphotic zone. Whatever the details of its diet, the quality and quantity of food available to $N$. megalops depends upon processes in the euphotic zone. Ortner et al. (in prep.) have shown that ring aging produces a shift toward lower phytoplankton standing crop, smaller cell size, greater phytoplankton species diversity, and somewhat lower production. All of these changes alter primary production patterns so that they more closely resemble those of the Sargasso Sea. Moreover, zooplankton biomass in the upper $200 \mathrm{~m}$ declines as a consistent feature of ring aging. It is inevitable that these changes have profound effects on the food supply of $N$. megalops. The poor physiological state of this species in the ring as evidenced by changes in respiratory rate and chemical composition and by reductions in the rate of growth in terms of carapace lengths and wet weights probably reflects altered food supply.

Our respiration rate experiments primarily indicated the relative inability of ring individuals to withstand the additional stress of a respiration experiment. Slope Water animals survived these experiments and were apparently active enough to respire at fairly high rates. Raymont and Conover (1961) recorded oxygen consumption for $N$. megalops of $110-140 \mu 10_{2} / \mathrm{g} / \mathrm{hr}$ whereas our values averaged $680 \mathrm{ml} 0_{2} / \mathrm{g} / \mathrm{hr}$ for Slope Water animals and only $70 \mu 1 \mathrm{O}_{2} / \mathrm{g} / \mathrm{hr}$ for ring animals. Comparisons of respiration rates are difficult due to the variations induced by differences in activity. While our values for ring and Slope Water N. megalops may differ in part due to activity differences, such a difference is in itself indicative of the better condition of Slope Water animals.

No differences in body lipid are evident between the Slope Water and ring in- 
dividuals after six months, although the decline in percent nitrogen suggests that protein was used for energy metabolism. The decline in body lipid in ring individuals observed from 6 to 9 months is most likely attributable to the breakdown of constitutive lip0-protein during starvation. $N$. megalops during the study period had a relatively low lipid content in its natural condition and apparently did not possess substantial storage lipid, hence partial starvation immediately induced protein breakdown. It is possible that total lipids were conserved or maintained during the first six months for ring animals, but subsequently were utilized. This may explain the decline in lipid from six to nine months.

Changes in sex ratios in crustacean plankton accompanying dietary deficiencies have been documented by Omori (1970), Ikeda (1971), and Conover (1964), who showed that males predominate in unfavorable conditions. It was suggested that the similarity of adult male body form to previous stages may favor their transformation to adult males. Mednikov (1961) explained the predominance of females in deep sea copepods as an adaptation to increase fecundity in a food-limited population. Butler (1964) found that the hermaphroditic decapod Pandalus danae functions first as a male and then as a female. Sex ratios changed as the animal was carried farther from its home range.

Our study has shown a reduction of adult males in the ring by six months and their total absence after nine months. They may have been selectively eliminated from the population by some factor in their environment, although it is difficult to envision any exogenous factor with such dramatic sex selectivity. A more likely explanation involves the fact that our criterion for determining sex depends solely on the presence or absence of male characteristics. The variability of secondary sexual characteristics in adult-sized individuals on both ring cruises suggests that immature males may either be hampered in their transformation to normal adults or that mature males are retrogressing into a nonreproductive male form, indistinguishable by our criterion from the female form.

Despite the evidence showing a definite decline in the physiological state of the population age class reduction, and disappearance of mature adult males, abundance estimates of ring $N$. megalops increases nearly 7 -fold between 6 and 9 months. Ordinarily, an increase in abundance might indicate the growth of a healthy population. Evidence presented above indicates that the population is in fact not healthy.

Although other explanations may be invoked to account for the increase in catch rate in the 9 month ring, such as patchiness and sampling error, the physiological and biochemical data coupled with the reduced discrepancy between day and night catches (see Wiebe and Boyd, 1978), lead us to postulate that the increased catch resulted from a decreased efficiency of net avoidance by animals in a weakened condition. Varibility in responses to sensory inputs have been suggested to account for relative changes in avoidance (Mauchline and Fisher, 1969; Har- 
risson, 1967). Barham (1970) has observed mesopelagic fishes and found increasing states of exhaustion cause greater capture vulnerability. If the net avoidance capabilities of stressed populations are reduced, increases in numbers caught may only reflect poor physiological condition rather than increased abundance. Our data suggest that abundance estimates per se are not sufficient to determine the viability of stressed populations.

Although the assessment of the physiological state of zooplankton is undoubtedly a complex issue, we believe that relatively simple measurements can be used as indicators. Perhaps the most useful index of nutritional condition is the measurement of carbon and nitrogen as a percentage of wet weight. The comparison of these indices between a normal "control" area and a suspected stressful environment may prove to be a valuable tool for establishing the unstressed limits of a population.

Acknowledgments. We wish to express our sincere appreciation to Drs. Peter Ortner and Loren Haury for their assistance in critiquing the manuscript and Lawrence Drueker for his perseverance in the respiration measurements. This is contribution No. 3938 from the Woods Hole Oceanographic Institution, Woods Hole, Massachusetts 02543. It was supported by the Office of Naval Research Contracts N00014-66-C0241 NR083-004; N00014-74-C0262 NR083004 and the National Science Foundation grant DES74-02783A01.

\section{REFERENCES}

Bamstedt, U. 1975. Ecological aspects of individual variations in weight, protein and lipid content of Euchaeta norvegica (copepod), Sarsia, 59, 31-46.

Barham, E. G. 1970. Deep sea fishes. Lethargy and vertical orientation, p. 100-118, in Proceedings of an International Symposium on Biological Sound Scattering in the Ocean, G. B. Farquhar, ed., U.S. Naval Oceanogr. Office. 629 pp.

Bligh, E. G., and W. J. Dyer. 1959. A rapid method of total lipid extraction and purification. Can. J. Biochem. Physiol., 37, 911-917.

Butler, T. H. 1964. Growth, reproduction and distribution of pandalid shrimps in British Columbia. J. Fish. Res. Bd. Can., 21, 1403-1452.

Childress, J. J. 1977. Physiological approaches to the biology of midwater organisms, in Oceanic Sound Scattering Prediction, N. R. Andersen and B. J. Zahuranec, eds., Marine Science, Vol. 3. New York, Plenum Press, 301-324.

Conover, R. J. 1964. Food relations and nutrition of zooplankton. Proc. Symp. Exp. Mar. Ecol., Univ. Rhode Island Occ. Publ. 2, 81-91.

Folch, J., M. Lees and G. H. Sloane Stanley. 1956. A simple method for the isolation and purification of total lipids from animal tissues. J. Biol. Chem., 226(a), 497-509.

Gopalakrishnan, K. 1974. Zoogeography of the genus Nematoscelis (Crustacea, Euphausiacea). Fishery Bull., 72, 1039-1074.

Greunbaum, B. W., B. V. Siegel, A. R. Schultz and P. L. Kirk. 1955. Determination of oxygen uptake by tissue grown in an all glass differential microrespirometer. Microchimica Acta, 6, 1069-1075.

Harrisson, C. M. H. 1967. One method for sampling mesopelagic fishes, p. 71-126, in Aspects of Marine Zoology, N. B. Marshall, ed., Symp. Zool. Soc. Lond. No. 19, New York, Academic Press, 270 pp. 
Ikeda, T. 1971. Changes in respiration rate and body size in marine plankton animals as a function of the temperature of habitat. Bull. Fac. Fish., Hokkaido Univ., 21, 280-298.

- 1974. Nutritional ecology of marine zooplankton. Mem. Fac. Fish. Hokkaido Univ., 22, $1-97$.

Littlepage, J. L. 1964. Seasonal variation in lipid content of two antarctic marine Crustacea. Actual Scient. Ind., 1312, 463-470.

Mauchline, J. and L. R. Fisher. 1969. The biology of euphausiids, in Advances in Marine Biology, F. S. Russel and M. Yonge, eds., New York, Academic Press, 7, 454 pp.

Mayzaud, P. 1976. Respiration and nitrogen excretion of zooplankton. IV. The influence of starvation on the metabolism and biochemical composition of some species. Mar. Biol., 37, $45-58$.

Mednikov, B. M. 1961. On the sex ratio in deep water Calanoida. Crustaceana, 3, 105-109.

Omori, M. 1970. Variations of length, weight, respiratory rate, and chemical composition of Calanus cristatus in relation to its food and feeding, p. 113-126, in Marine Food Chains, J. H. Steele, ed., Edinburgh, Oliver and Boyd, 552 pp.

Orr, A. P. 1934a. The weight and chemical composition of Euchaeta norvegica Boeck. Proc. Roy. Soc. Edinb., B 54, 51-55.

- 1934b. On the biology of Calanus finmarchicus. IV. Seasonal changes in the weight and chemical composition in Loch Tyne. J. Mar. biol. Ass. U.K., 19, 613-632.

Ortner, P. B., E. M. Hulburt, and P. H. Wiebe. Phytohydrography and herbivore habitat contrasts in the northwestern Atlantic Ocean. In manuscript.

Parker, C. E. 1971. Gulf Stream rings in the Sargasso Sea. Deep-Sea Res., 18, 981-993.

Raymont, J. E. G. and R. J. Conover. 1961. Further investigations on the carbohydrate content of marine zooplankton. Limnol. Oceanogr., 6, 154-164.

Rudd, J. T. 1936. Euphausiacea Report. Dana Oceanogr. Exped. Mediterr., 2 (Biol.), Sect. D, part 6,86 pp.

Wiebe, P. H., E. M. Hulburt, E. J. Carpenter, A. E. Jahn, G. P. Knapp III, S. H. Boyd, P. B. Ortner and J. L. Cox. 1976. Gulf Stream cold core rings: large scale interaction sites for open ocean plankton communities, Deep-Sea Res., 23, 695-710.

Wiebe, P. H. and S. H. Boyd. 1978. Limits of Nematoscelis megalops in the Northwestern Atlantic in relation to Gulf Stream cold core rings. I. Horizontal and vertical distribution. J. Mar. Res., this issue.

Received: 12 July, 1977; revised: 10 December, 1977. 
Printed in U.S.A. for the Sears Foundation for Marine Research,

Yale University, New Haven, Connecticut, 06520, U.S.A.

Van Dyck Printing Company, North Haven, Connecticut, 06473, U.S.A. 
MANDATORY DISTRIBUTION LIST

FOR UNCLASSIFIED TECHNICAL REPORTS, REPRINTS, AND FINAL REPORTS PUBLISHED BY OCEANOGRAPHIC CONTRACTORS

OF THE OCEAN SCIENCE AND TECHNOLOGY DIVISION

OF THE OFFICE OF NAVAL RESEARCH

(REVISED NOVEMBER 1978)

1 Deputy Under Secretary of Defense (Research and Advanced Technology) Military Assistant for Environmental Science Room 3D129

Washington, D.C. 20301

Office of Naval Research 800 North Quincy Street

Arlington, VA 22217

3 ATTN: Code 483

1 ATTN: Code 460

2 ATTN: 102B

1 CDR J. C. Harlett, (USN) ONR Representative Woods Hole Oceanographic Inst. Woods Hole, MA 02543

Commanding Officer Naval Research Laboratory Washington, D.C. 20375

6 ATTN: Library, Code 2627
12 Defense Documentation Center Cameron Station Alexandria, VA 22314 ATTN: DCA

Commander Naval Oceanographic Office NSTL Station

Bay St. Louis, MS 39522

1 ATTN: Code 8100

1 ATTN: Code 6000

1 ATTN: Code 3300

1 NODC/NOAA

Code D781

Wiscons in Avenue, N.W. Washington, D.C. 20235 


\begin{tabular}{|c|c|}
\hline REPORT DOCUMENTATION PAGE & $\begin{array}{l}\text { READ INSTRUCTIONS } \\
\text { BEFORE COMPLETING FORM }\end{array}$ \\
\hline $\begin{array}{l}\text { 1. REPORT NUMBER } \\
\text { WHOI-79-13 }\end{array}$ & 3. RECIPIENT'S CATALOG NUMBER \\
\hline \multirow{2}{*}{$\begin{array}{l}\text { 4. TITLE (and Subtitle) } \\
\text { LIMITS OF NEMATOSCELIS MEGALOPS IN THE NORTH- } \\
\text { WESTERN ATLANTIC IN RELATION TO GULF STREAM } \\
\text { COLD CORE RINGS. II. PHYSIOLOGICAL AND BIO- } \\
\text { CHEMICAL EFFECTS OF EXPATRIATION }\end{array}$} & $\begin{array}{l}\text { 5. TYPE OF REPORT A PERIOD COVERED } \\
\text { Technical }\end{array}$ \\
\hline & $\begin{array}{l}\text { 6. PERFORMING ORG. REPORT NUMBER } \\
\text { WHOI CON. NO. } 3938\end{array}$ \\
\hline $\begin{array}{l}\text { 7. AUTHOR(s) } \\
\text { Steven H. Boyd, Peter H. Wiebe and James L. Cox }\end{array}$ & $\begin{array}{l}\text { 8. CONTRACT OR GRANT NUMBER(s) } \\
\text { NO0014-66-C-0241; } \\
\text { NO0014-74-C-0262; } \\
\text { DES } 74-02783 \text { AOI }\end{array}$ \\
\hline $\begin{array}{l}\text { 9. PERFORMING ORGANIZATION NAME AND ADDRESS } \\
\text { Woods Hole Oceanographic Institution } \\
\text { Woods Hole, MA } 02543\end{array}$ & $\begin{array}{l}\text { 10. PROGRAM ELEMENT, PROJECT, TASK } \\
\text { AREA Q WORK UNIT'NUMEERS } \\
\text { NR } 083-004 .\end{array}$ \\
\hline $\begin{array}{l}\text { 11. CONTROLLING OFFICE NAME AND ADDRESS } \\
\text { NORDA }\end{array}$ & $\begin{array}{l}\text { 12. REPORT DATE } \\
\text { January } 1979\end{array}$ \\
\hline $\begin{array}{l}\text { National Space Technology Laboratory } \\
\text { Bay St. Louis, MS } 39529\end{array}$ & 13. NUMBER OF PAGES \\
\hline 14. MONITORING AGENCY NAME \& ADDRESS(If different from Controlling Offico) & $\begin{array}{l}\text { 15. SECURITY CLASS. (of this roport) } \\
\text { Unclassified }\end{array}$ \\
\hline & $\begin{array}{l}\text { 15a. DECLASSIFICATION/DOWNGRADING } \\
\text { SCHEDULE }\end{array}$ \\
\hline
\end{tabular}

Approved for public release; distribution unlimited.

17. DISTRIBUTION STATEMENT (of the abstract entered in Block 20, if different from Report)

18. SUPPLEMENTARY NOTES

Reprinted from "Journal of Marine Research, Volume 36, 1, 1978, pp. 143-159".

19. KEY WORDS (Continue on reverse side if necessary and Identify by block number)

1. Cold core rings

2. Nematoscelis megalops

2. Zooplankton ecology

20. ABSTRACT (Continue on reverae efde if neceesery and identify by block number)

Nematoscelis megalops, a cold water euphausiid commonly found in Northwestern Atlantic slope Water, is frequently transported in the cores of Gulf Stream cyclonic rings into the Sargasso Sea. The inner core made of cold slope Water gradually assumes physical and biological characteristics of the surround ing Sargasso Sea. These changes gradually lead to a localized extinction of this species in the core of the ring. Samples of $N$. megalops taken from the same ring at 6 and 9 months after its formation show a weakened (Cont. on back) 
physiological and biochemical condition.

Deterioration of ring individuals is evidenced by an increase in body water content and a reduction in total body lipid, carbon, respiration rates, and nitrogen relative to Slope Water individuals. By 6 months it appears that ring $N$. megalops must supplement food intake by netabolizing some of their body protein and by 9 months they appear to use lipids as well.

A shipboard starvation experiment involving 40 slope Water individuals showed that physiological and blochemical states similar to those found in individuals from the 9 months old ring could be duplicated in 4 days of complete starvation. 


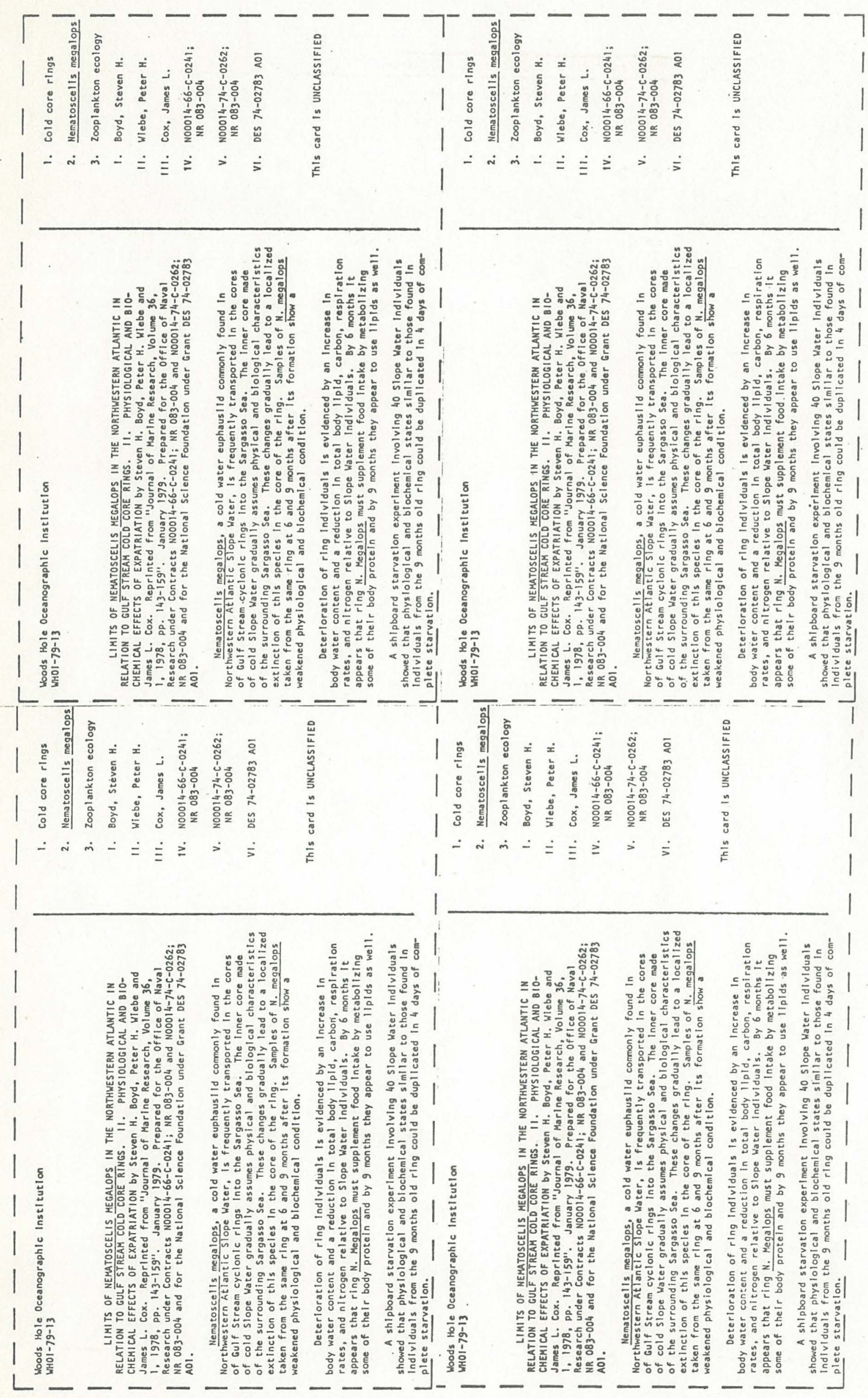

